\begin{tabular}{|c|c|}
\hline $\begin{array}{l}\text { Sciendo } \\
\qquad \begin{array}{c}\text { RURAL SUSTAINABILITY RESEARCH 41(336), } 2019 \\
\text { ISSN - 2256-0939 } \\
\text { (c) Latvia University of Life Sciences and Technologies, } \\
\text { all rights reserved } \\
\text { http://www.llu.lv/en/ }\end{array}\end{array}$ & RUt \\
\hline
\end{tabular}

\title{
Investigating Post-partum Ovarian Cyclicity Following Various Treatments in Dairy Cows
}

\author{
*Akshay Sharma, Madhumeet Singh, Pravesh Kumar and Pradeep Kumar Dogra \\ DGCN College of Veterinary and Animal Sciences, CSK Himachal Pradesh KrishiVishvavidyalaya, \\ Palampur (H.P.), India
}

\begin{abstract}
The present study envisages the effect of $\mathrm{PGF}_{2 \alpha}$ and antibiotic treatment on ovarian cyclic activity and regression of corpus luteum verum in post-partum dairy cows. Cows were divided into three treatment (PG8, PG25, antibiotic) and a control group. Ovarian activity was studied by examining follicular dynamics upto 42 days post-partum in which diameter of dominant follicle before first ovulation, the number of days to first ovulation and complete regression of corpus luteum verum were evaluated. Body condition score was recorded for all the cows in different groups. Also, ovulation on ovary ipsilateral or contralateral to previous gravid uterine horn was noted. On transrectal ultrasonography at a 3-day interval, dominant follicle diameter prior to ovulation was significantly higher $(\mathrm{p}<0.01)$ in PG8 group. The mean time required for complete regression of $\mathrm{CL}$ verum was not significantly $(\mathrm{p}>0.05)$ lower in $\mathrm{PG} 8$ group i.e. $24.33 \pm 1.48$ days in comparison to $\mathrm{PG} 25$, antibiotic and control group $(26.67 \pm 1.48,29.00 \pm 1.81$ and $27.60 \pm 1.40$ days post-partum, respectively). A subsequent ovarian activity was affected as 70.83 and $66.33 \% \mathrm{Ist}^{\mathrm{st}}$ and $\mathrm{IId}^{\text {nd }}$ ovulations occurred on the ovary contralateral to corpus luteum verum. In conclusion, contralateral ovary was more active in terms of ovulation whereas presence of corpus luteum verum had no effect on post-partum ovarian cyclic activity.
\end{abstract}

Keywords: body condition score, corpus luteum verum, dairy cows, $\mathrm{PGF}_{2 a}$, ovarian cyclicity, ultrasonography.

\section{Introduction}

Ovarian activity plays an irreplaceable role in the chain of events leading to pregnancy and delivery. Each cow needs to calve regularly in order to maximize the economic output of milk production. Post-partum ovarian cyclic activity is beneficial for reproductive health and successive fertility (Sharma et al., 2018). Emergence of the first follicular wave and selection of the dominant follicle (DF), which can ovulate or develop into a cyst or non-ovulatory follicle is the crucial event inpost-partum ovarian cyclic activity (Rajmonet al., 2012). Therefore, management practices which help in early resumption of ovarian cyclic activity should be followed to improve further reproductive performance (Cerri et al., 2004). Administration of $\mathrm{PGF}_{2 \alpha}$ after parturition enhances uterine contractility and lochial clearing from the uterus which helps in clearance of uterine infection and timely resumption of ovarian cyclic activity (Nanda, Brar, \& Prabhakar, 2003). In improving the uterine defense and uterine clearance mechanism and consequently reducing persistent inflammation, antibiotic administration is required (McDougall, 2001). Therefore, the present study was conducted to investigate the effect of $\mathrm{PGF}_{2 \alpha}$ and antibiotic treatment on ovarian cyclic activity and regression of corpus luteum verum in post-partum dairy cows.

\section{Materials and Methods}

Twenty Jersey crossbred post-partum dairy cows (Parity 2-5) of Livestock farm, CSKHPKV, Palampur were enrolled for study. Cows were divided into three treatment and a control group. The first two treatment groups were administered $500 \mathrm{mcg}^{\mathrm{PGF}} \mathrm{F}_{2 \alpha}$ analogue (Cloprostenol; Zydus Animal Health Ltd.) intramuscularly either on day 8 (PG8) or 25 (PG25) postpartum. In the third group, cows were administered antibiotic Ciprofloxacin@4mgkg-1 body wt. intramuscularly for first 5 days after calving (C-Flox Power; Intas Pharmaceuticals Ltd.). The fourth group served as an untreated control.

\footnotetext{
* Corresponding Author's email: 
Transrectal ultrasonography was done immediately after parturition using linear transducer of frequency 7.5 MHz (Sonosite M turbo; Sonosite India Pvt. Ltd.) on a 3-day interval upto day 42 postpartum to assess the size of dominant follicle, subsequent ovulation on contralateral and ipsilateral ovary was recorded. Day of complete regression of corpus luteum verum was also noted. Body condition score (BCS) of the cows was recorded at the time of calving using five point scale of scoring (Edmonson et al., 1989). The data was statistically analyzed using one-way ANOVA with SAS (Statistical Analysis Software), SAS 9.2 TS Level version 2M2 for windows.

\section{Results and Discussion}

The mean size of ovulatory dominant follicle (Figure 1), first post-partum ovulation (Figure 2) and regression of corpus luteum verum (Figure 3-6) and BCS have been shown in Table 1. However, the relationship of side of CL verum, subsequent ovarian cyclic activity and body condition score (BCS) at calving in post-partum dairy cows have been shown in Table 2.

Mean follicular diameter for cows administered $\mathrm{PGF}_{2 \alpha}$ on day 8 after parturition was significantly higher $(\mathrm{P}<0.01)$ as compared to other groups. The first ovulation post-partum is silent and followed by a short cycle. Mean time taken for the first ovulation was significantly earlier $(\mathrm{P}<0.01)$ in $\mathrm{PG} 8$ group as compared to other groups in our study. Post-partum ovulation has been reported at $21.20 \pm 9.60$ days post-partum in cows whereas first dominant follicle was evident at $8.3 \pm 3.7$ day post-partum (Kamimura et al., 1993). Sharma et al. (2018) also found a positive effect on resumption of ovarian cyclicity following administration of $\mathrm{PGF}_{2 \alpha}$.

Size of ovulatory dominant follicle $(\mathrm{mm})$ and regression of corpus luteum verum (days)

Table 1 following different treatments after parturition in dairy cows (Mean \pm S.D.)

\begin{tabular}{|c|c|c|c|c|}
\hline $\begin{array}{c}\text { Treatment } \\
(\mathrm{n}=5)\end{array}$ & $\begin{array}{c}\text { Ovulatory dominant } \\
\text { follicle size (mm) }\end{array}$ & $\begin{array}{c}\text { First post-partum } \\
\text { ovulation (d) }\end{array}$ & $\begin{array}{c}\text { Complete regression } \\
\text { of CL verum (d) }\end{array}$ & BCS at calving \\
\hline PG 8 & $12.86 \pm 0.39^{\mathrm{a}}$ & $17.16 \pm 1.22^{\mathrm{a}}$ & $24.33 \pm 1.48$ & $2.62 \pm 0.07$ \\
\hline PG 25 & $10.13 \pm 0.27^{\mathrm{b}}$ & $28.83 \pm 1.16^{\mathrm{b}}$ & $26.67 \pm 1.48$ & $2.58 \pm 0.09$ \\
\hline Antibiotic & $9.67 \pm 0.26^{\mathrm{b}}$ & $27.67 \pm 1.12^{\mathrm{b}}$ & $29.00 \pm 1.81$ & $2.56 \pm 0.14$ \\
\hline Control & $9.75 \pm 0.40^{\mathrm{b}}$ & $27.20 \pm 1.58^{\mathrm{b}}$ & $27.60 \pm 1.40$ & $2.63 \pm 0.12$ \\
\hline
\end{tabular}

${ }^{a, b}$ Values with different superscripts within the same column differ significantly $(\mathrm{P}<0.01)$.

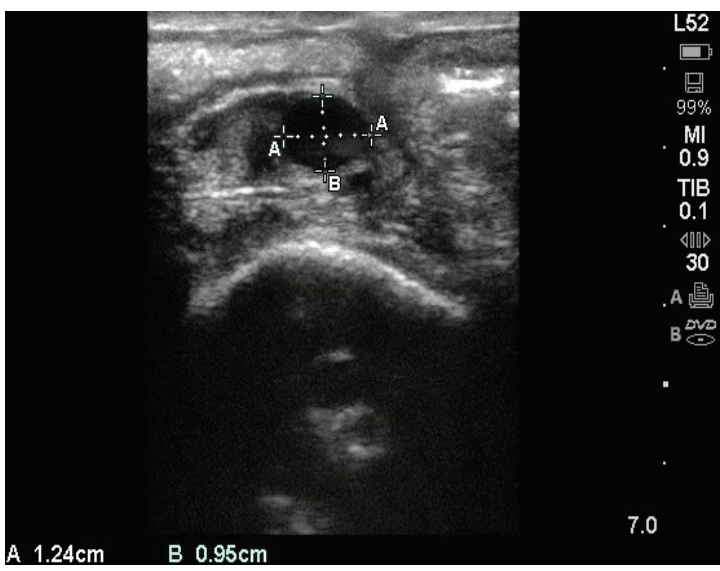

Figure 1. Ultrasound image of a dominant follicle which appears black and is considered as ovulatory $(12.4 \times 9.5 \mathrm{~mm})$.

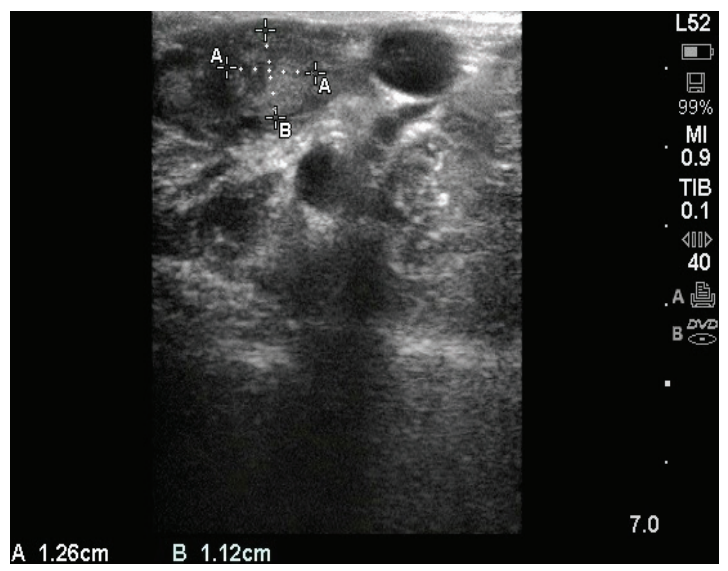

Figure 2. Ultrasound image of first corpus luteum $(12.6 \times 11.2 \mathrm{~mm})$ which appears greyish (hyperechoic). 


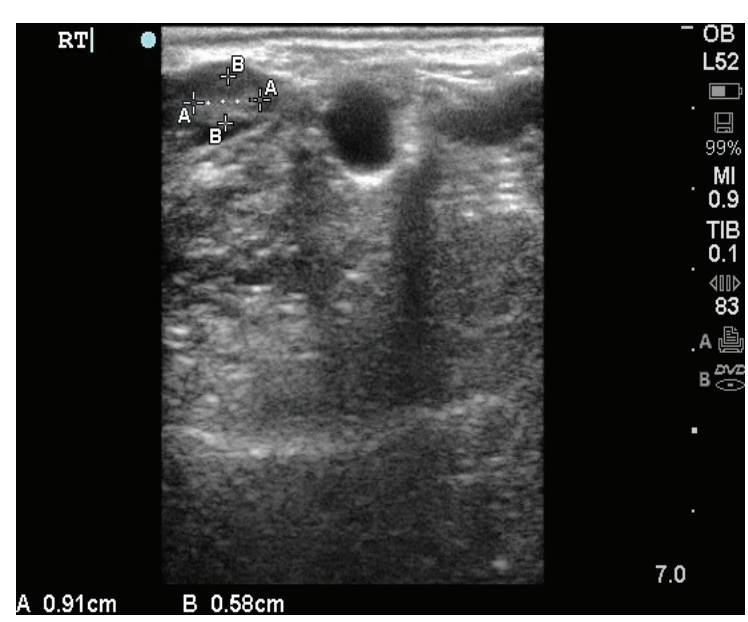

Figure 3.A and B showing presence of CL verum (approx. $7.4 \mathrm{~mm}$ ) on day 8 post-partum.

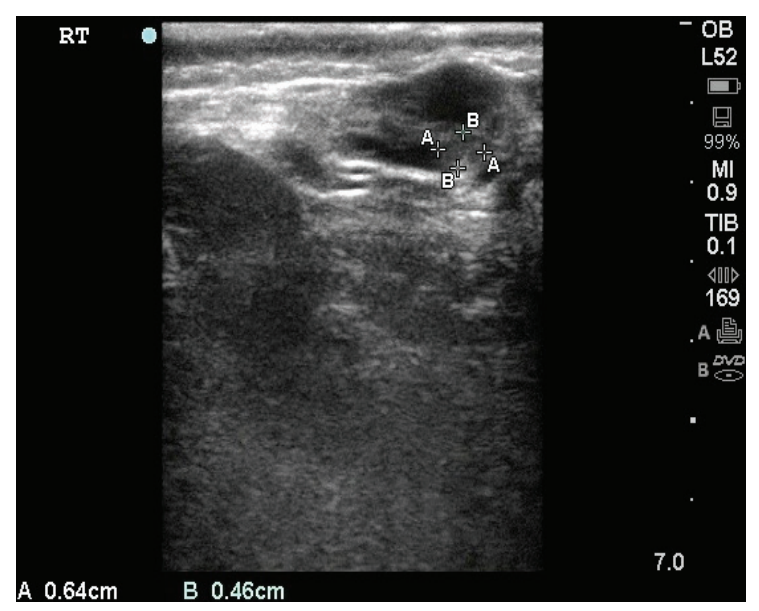

Figure 5. More decrease in size of CL verum is evident on day 22 post-partum (approx. $5.5 \mathrm{~mm}$ ).
Following Various Treatments in Dairy Cows

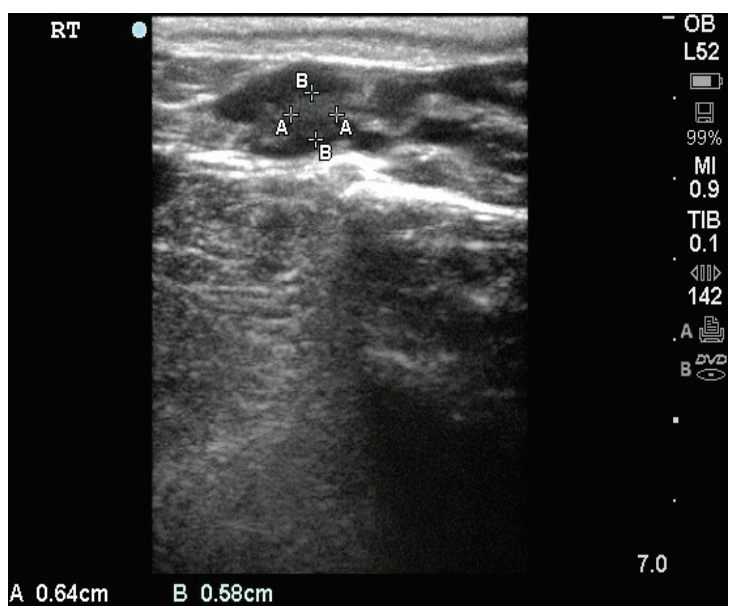

Figure 4. Decrease in size of CL verum on day 15 post-partum (approx. $6.1 \mathrm{~mm}$ ).

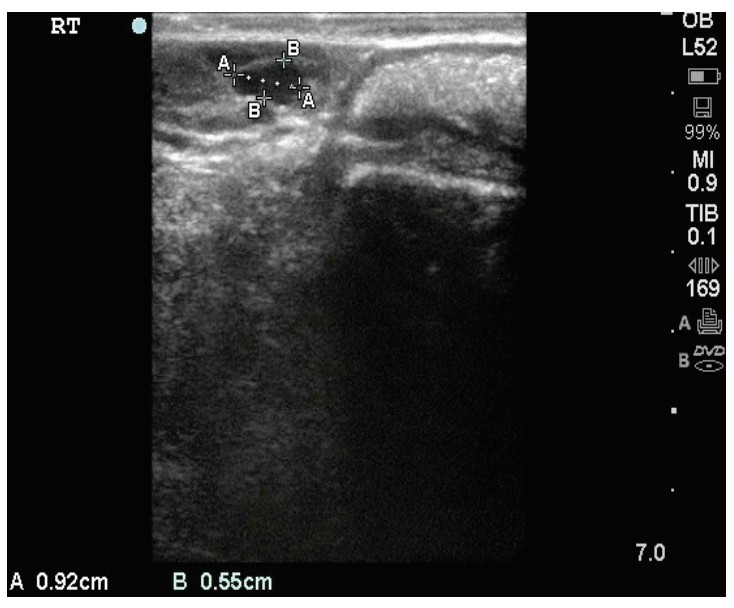

Figure 6. Complete regression of CL verum and presence of emerging follicle on day 29 post-partum

Relationship of side of CL verum and subsequent ovarian cyclic activity in post-partum dairy cows

\begin{tabular}{|c|c|c|c|c|c|}
\hline \multirow{2}{*}{\multicolumn{2}{|c|}{$\begin{array}{c}\begin{array}{c}\text { Number of ovulations post- } \\
\text { partum }\end{array} \\
\text { Side of ovary }\end{array}$}} & \multicolumn{2}{|c|}{ 1st ovulation } & \multicolumn{2}{|c|}{ 2nd ovulation } \\
\hline & & Contralateral & Ipsilateral & Contralateral & Ipsilateral \\
\hline \multirow{5}{*}{$\begin{array}{l}\text { Treatment } \\
\text { Groups } \\
(\mathrm{n}=5)\end{array}$} & PG 8 & 4 & 2 & 3 & 3 \\
\hline & PG 25 & 5 & 1 & 4 & 2 \\
\hline & Antibiotic & 4 & 2 & 5 & 1 \\
\hline & Control & 4 & 2 & 4 & 2 \\
\hline & Total & $\begin{array}{c}17 \\
70.83 \%\end{array}$ & $\begin{array}{c}7 \\
29.17 \%\end{array}$ & $\begin{array}{c}16 \\
66.33 \%\end{array}$ & $\begin{array}{c}8 \\
33.67 \%\end{array}$ \\
\hline
\end{tabular}


Complete regression of $\mathrm{CL}$ verum was not having significant difference between the treatment and control group (Table 1). Labhsetwar et al. (1964) revealed that $C L$ verum was mainly a structural entity with no progesterone being secreted by it either on the day of parturition or at day 21 postpartum. Also, Patel et al. (2005) reported that even if CL verum persists for about 2 weeks post-partum, it does not prevent follicular development. Body condition score (BCS) recorded at the time of calving by the visual technique on 1-5 point scale of all the cows included in the study and it was not significantly different $(\mathrm{P}>0.05)$ in all the cows under different groups i.e. PG8, PG25, the antibiotic and control group.

In majority of the cows, the first (70.83\%) and second $(66.33 \%)$ ovulation occurred on the contralateral ovary to the previous gravid uterine horn. In concurrence to our findings, Kamimura et al. (1993) stated that there is a great predilection for folliculogenesis on the contralateral ovary in the first four weeks after parturition. Similarly, Usmani et al. (1992) reported that this may be due to less selection of dominant follicles on the ipsilateral ovary. Sheldon et al. (2003) also confirmed that previous gravid uterine horn could suppress the localized function of ovarian function of ipsilateral ovary. Thus, timely uterine involution and elimination of bacterial contamination can facilitate the ovarian function on the ipsilateral ovary.

\section{Conclusions}

1. Ovulation from a larger dominant follicle occurred in cows after administration of $\mathrm{PGF}_{2 \alpha}$ on day 8 after parturition, whereas BCS was found to be non-significantly higher in control group.

2. Presence of regressing corpus luteum verum had no effect on follicular dynamics in postpartum dairy cows.

3. Post-partum ovarian activity/ ovulation occurred mostly on contralateral ovary to the previous gravid uterine horn.

\section{References}

1. Cerri, R.L.A., Santos, J.E.P., \& Juchem. S.O., Galvao, K.N., Chebel, R.C. (2004). Timed artificial insemination with estradiol cypionate or insemination at estrus in high-producing dairy cows. Journal of Dairy Science, 87(11), 3704-3715.

2. Edmonson, A.J., Lean, I.J., Weaver, L.D., Farver, T. and Webster, G. (1989). A body condition scoring chart of Holstein dairy cows. Journal of Dairy Science, 72(1), 68-78.

3. Kamimura, S., Ohgi, T., \& Takahashi, M., Tsukamoto, T. (1993). Postpartum resumption of ovarian activity and uterine involution monitored by ultrasonography in Holstein cows. Journal of Veterinary Medical Science, 55(4), 643-664.

4. Labhsetwar, A.T., Collins, W.E., \& Tyler, W.J., Casida, L.E. (1964). Some pituitary ovarian relationships in the periparturient cow. Journal of Reproduction and Fertility, 8, 85.

5. McDougall, S. (2001). Effect of intrauterine antibiotic treatment on reproductive performance of dairy cows following periparturient disease. New Zealand Veterinary Journal, 49, 150-158.

6. Nanda, A.S., Brar, P.S., \& Prabhakar, S. (2003). Enhancing the reproductive performance in dairy buffaloes: major constrains and achievement. Reproduction Supplement, 61, 27-36.

7. Patel, P.M., Dhami, A.J., \& Kalyani, I.H. (2005). Puerperal events, bacterial isolates of cervico-vaginal mucus and reproductive performance of cows. Indian Veterinary Journal, 82, 759-762.

8. Rajmon, R., Sichtar, J., \& Vostry, L., Rehak, D. (2012). Ovarian follicle growth dynamics during the postpartum period in Holstein cows and effects of contemporary cyst occurrence. Czech Journal of Animal Science, 57(12), 562-572.

9. Sharma, A., Singh, M., \& Sharma, A., Kumar, P. (2018). Prostaglandin F2 $\alpha$ administration on day 8 postpartum leads to early resumption of ovarian cyclic activity in dairy cattle. Indian Journal of Animal Reproduction 39(1), 38-40.

10. Sheldon, I.M., Noakes, D.E., \& Rycroft, A.N., Dobson, H. (2003). The effect of intrauterine administration of estradiol on postpartum uterine involution in cattle. Theriogenology, 59, 1357-1371.

11. Usmani, R.H. (1992). Effect of non-gravid uterine horn on pattern of resumption of ovarian functions in postpartum Nile Ravi buffaloes. Buffalo Journal, 8, 256-270. 